\title{
Child advocacy and the Queen's representative; an unlikely link
}

n Australia, as in many other countries, we find it immensely difficult to get children's issues on the radar screens of politicians or newspaper editors. Occasionally we get stories about the lack of childcare places, or concern about numbers of children diagnosed with attention deficit-hyperactivity disorder and who have medications prescribed for them. And from time to time there are distressing accounts of child physical or sexual abuse.

These little blips on the radar screen are inevitably of short duration, and quickly disappear into the dustbin of yesterday's news. The children's issues that do get into the public consciousness are usually so transient that they are unlikely to threaten the comfort zones of politicians or bureaucrats or disturb their sleep habits.

One of the reasons that children's issues don't seem to gather much momentum is that they are often reported locally. Australia is a federation with clearly defined differing roles of commonwealth and state governments. This means that the array of services that cater for young children and their families is a shared responsibility between the different levels of government, a situation that creates ideal conditions for evasion of responsibility and for buck passing. This confusing hybrid of funding arrangements between commonwealth and state governments has been identified repeatedly as the greatest barrier to the reform of children's services in this countrymore on this some other time.

However, over recent months there has been an extraordinary amount of national attention paid to an important child health issue, even though in an oblique manner. Child sexual abuse has been the topic of intense and sustained media attention. But let me start from the beginning.

Australia is in the unusual (and some would say unbelievable in this day and age) position of still looking to the Queen of England as our head of state. This status is largely ceremonial, though not so long ago the Queen's representative in Australia did dismiss a popularly elected government. The GovernorGeneral of Australia is appointed by the Queen of England on the recommendation of the Australian Prime Minister. He (it has never been a "she") is usually an eminent person with a background of service to the community; the majority in recent times have been from the judiciary. Their duties consist of having to take up residence in a stately mansion in Canberra complete with a host of servants, instantly becoming patron of dozens of charities and service organisations around the country, entertaining visiting dignitaries, giving the occasional speech, and other such tasks as to set the heart racing.

In June 2001 Peter Hollingworth was appointed to the post of GovernorGeneral of Australia. He seemed to have the necessary attributes for the job-a long record of community service, prominent in government circles, well known to the masses, and so on. However his appointment caused great consternation on several counts. First the Republicans were up in arms, claiming that this vestige of colonialism has certainly passed its use-by-date (opinion polls show consistently that a significant majority of Australians favour Australia becoming a Republic). Second was the fact that Hollingworth is of the cloth, having been most recently prior to his appointment the Anglican Archbishop of Brisbane. It was argued that not only did this blur the traditional separation of church and state, but was an entirely inappropriate appointment in the multicultural, largely secular Australia of the 21st century. But worse was to come.

Some months ago it was claimed that while Archbishop of Brisbane in the 1990s, Hollingworth had mishandled allegations of child sexual abuse perpetrated by clergymen. Among other criticisms, it was said that he had allowed a priest to remain in the Ministry after he had admitted sexually abusing a child. Hollingworth was the subject of a programme shown on national television in which he admitted that he may have made errors of judgement, but then later in the same programme implied that all the blame should not have laid on the clergyman as the young woman may have come on to him, to use the vernacular. A church enquiry subsequently accused him of having been unsympathetic and lacking in compassion, as well as confirming that he had made serious errors of judgement.

Suddenly sexual abuse was in the news, on the front page of newspapers, and on talk-back radio every day for many weeks. A number of child welfare organisations, including those which were established to protect the rights of children, demanded in no uncertain terms that the Governor-General step down as their patron. There were calls for his resignation as it was suggested he was a person unfit to hold such a prominent national office. He resisted these calls, and was supported in this stance by the Prime Minister. Week by week the issue gained more momentum. The issue of child sexual abuse and its management was pulled along by the current and achieved a national media prominence hitherto unheard of. It also provided the opportunity for child advocates and those working with abused children to be given air space and many column inches of newspapers to advocate for children.

At the end of May, Hollingworth finally resigned as Governor-General. A new Governor-General has been duly appointed. The saga has run its course and is not regarded as news any more. However, in its wash-up, there have been calls for a national enquiry (a Royal Commission) into child abuse; arguments put forward that there should be a national policy and service framework for child physical and sexual abuse; renewed calls by the Labor opposition for a Children's Commissioner to safeguard the rights of children; and so on. One might hope that one of the outcomes might be a better deal for children. On the other hand, if history is any guide, governments will simply "tough it out" until the issue dies away completely. Then it will be back to business as usual, and children will fall off the agenda again.

Frank Oberklaid Centre for Community Child Health, Royal Children's Hospital Melbourne, Flemington Road, Parkville, Victoria 3052, Australia; frank.oberklaid@rch.org.au 